\title{
Enhanced Methane Production from Pilot-Scale Anaerobic Digester Loaded with Rice Straw
}

\author{
Wendy Mussoline ${ }^{\mathrm{a},{ }^{*}}$, Giovanni Esposito ${ }^{\mathrm{a}}$, Piet Lens ${ }^{\mathrm{b}}$ and Andrea Giordano ${ }^{\mathrm{c}}$ \\ ${ }^{a}$ University of Cassino, via Di Biasio 43, 03043 Cassino, FR, Italy \\ ${ }^{b}$ UNESCO-IHE, Westvest 7, 2611 AX Delft (The Netherlands) \\ ${ }^{c}$ Acqua \& Sole, s.r.l., Manzola Fornace, 27014 Corteolona, PV, Italy
}

\begin{abstract}
A novel co-digestion approach was evaluated to determine if agricultural and industrial waste residues could efficiently degrade straw without pretreatment. Untreated rice straw was co-digested with pig wastewater and anaerobic sludge from the pulp and paper mill treatment process in a pilot-scale digester $\left(1 \mathrm{~m}^{3}\right)$ operated in dry, mesophilic conditions. The total weight ratio of dry straw to pig wastewater to sludge was 1 to 1.25 to 0.5 . The experiment was performed for a total of 153 days, however, the optimum period to balance the maximum energy output with the minimum retention time was determined to be 93 days. The addition of paper mill sludge accelerated VFA formation and gas production when compared to another pilot-scale digester operated under the same conditions without the sludge material. The straw in the pilot-scale digester with the sludge yielded $231 \mathrm{LCH}_{4} / \mathrm{kg} \mathrm{VS}$ within a 93-day digestion cycle compared to 189 days without the sludge. Daily leachate recirculation $\left(0.2 \mathrm{~m}^{3} / \mathrm{m}^{3}\right.$ straw-day), however, was not adequate for internal mixing and homogenization of the digester material. With adequate mixing, this co-digestion approach could enhance methane production and reduce the digestion time for untreated rice straw in a farm-scale digester.
\end{abstract}

Keywords: Anaerobic digestion, rice straw, methane, pilot-scale, paper mill.

\section{INTRODUCTION}

Energy production from lignocellulosic waste is advantageous because there is an abundant supply of agricultural waste residues available, it does not interfere with the provision of valuable food sources, and it offers a potential reduction of greenhouse gas emissions by removing these residues from the field and capturing the methane. Energy from rice straw can be produced from thermochemical processes such as pyrolysis, combustion or gasification [1-4]; however, these processes are energy intensive. Bioethanol production from rice straw via fermentation is also an option but this process is expensive and relatively low yields have been observed [5]. As in anaerobic digestion, the hydrolysis of cellulose is inhibited by lignin and pretreatment is required to enhance ethanol production $[5,6]$. Biogas production from rice straw via anaerobic digestion is considered to be one of the most environmentally friendly processes for converting biomass into energy $[7,8]$.

The challenge associated with the utilization of lignocellulosic wastes for energy recovery is that the lignin acts as a barrier and can inhibit microbial populations that perform hydrolytic conversion of cellulose [9]. Several studies have

*Address correspondence to this author at the University of Cassino, via $\mathrm{Di}$ Biasio 43, 03043 Cassino, FR, Italy; Tel: +(01) 813-638-2115:

Fax: +(39) 776-299-3939; E-mail: wendy.mussoline@unicas.it investigated pretreatment strategies that enhance microbial degradation of lignocellulosic wastes in the context of anaerobic digestion [10-13]. The major goal of this research is to avoid design complications and energy inputs by removing the pretreatment step and use a novel co-digestion approach with waste products. Co-digestion with other wastes has been shown to enhance methane production from lignocellulosic wastes [14], and co-digestion is a simpler and more feasible approach for farm-scale applications. Co-digestion of rice straw with animal manure provides an appropriate balance of nutrients for anaerobic systems [15], and increased biogas yields from rice straw co-digested with both cattle manure and piggery wastewater have been demonstrated $[16,17]$. An existing farm-scale system $\left(15,000 \mathrm{~m}^{3}\right)$ in Northern Italy converts rice straw into electricity using piggery wastewater alone to promote microbial fermentation in dry conditions (i.e. $\geq 20 \%$ total solids (TS) concentration) [18]. However, a long acclimation period (200 days) and slow digestion cycle (422 days) was observed. A practical option for improvement is to add an acclimated microbial population to reduce the start-up cycle and improve methane yields.

Sludge generated in the pulp and paper mill industry likely contains microbial populations that are already acclimated to lignin-containing waste material. Clostridium cellulovorans, for example, originate in wood chips [19] and they produce enzymes that are capable of degrading rice straw in 
Table 1. Total and Volatile Solids Concentrations of Raw Materials in Digester

\begin{tabular}{|c|c|c|c|}
\hline & Rice Straw & Piggery Wastewater & Paper Mill Sludge \\
\hline \hline TS (\%) & 64.4 & 1.1 & 17.0 \\
\hline VS (\%TS) & 88.7 & 40.2 & 62.4 \\
\hline
\end{tabular}

10 days [20]. To test this hypothesis, sludge was collected from an upflow anaerobic sludge blanket (UASB) reactor that is part of the initial stage of treatment for pulp and paper mill effluent. This effluent is generated from five different pulping facilities that employ different operational practices. An initial laboratory study demonstrated that co-digestion of rice straw with both piggery wastewater and UASB paper mill sludge could accelerate formation of volatile fatty acids (VFA) and produce higher methane yields (302 to 340 $\mathrm{L}_{\mathrm{N}} \mathrm{CH}_{4} / \mathrm{kgVS}$ ) than those generated with the piggery wastewater alone [21]. In the present work, a pilot-scale digester $\left(1 \mathrm{~m}^{3}\right)$ was operated with the same straw-inocula mixture and digestion conditions tested in previous lab-scale experiments to determine if this co-digestion approach could improve methane production and reduce digestion cycles for farmscale systems. The purpose of this work is to increase the scale of the laboratory experiments in order to simulate farm-scale conditions and determine if this co-digestion approach is an appropriate solution for large-scale applications. The premise of this work is unique because it proposes a codigestion approach with not only piggery wastewater (tested previously in a pilot-scale system) but also with anaerobic sludge from the pulp and paper mill treatment process to enhance methane production from untreated rice straw.

\section{MATERIAL AND METHODS}

\subsection{Experimental Set-up}

A single pilot-scale digester $\left(1 \mathrm{~m}^{3}\right)$ equipped with a leachate recirculation system was used for this experiment. The specific components and dimensions of the digester are described in a previous study [22]. The digester was operated as a batch reactor and initially filled with $50 \mathrm{~kg}$ of dry straw, $75 \mathrm{~kg}$ of piggery wastewater, and $25 \mathrm{~kg}$ of anaerobic sludge from the pulp and paper mill treatment process. This substrate to inocula ratio was determined to be the optimum ratio based on methane yields obtained in laboratory-scale digesters [21] and feasible application for a farm-scale system. The digester was operated in dry $(20 \%$ TS $)$, mesophilic conditions for a total of 153 days. Dry conditions are advantageous since they require significantly less water that wet conditions (i.e. $\leq 10 \% \mathrm{TS}$ ) and the farm-scale system is currently operated in dry conditions [18]. Mesophilic temperatures were chosen since optimal gas production from rice straw is within 35 to $40^{\circ} \mathrm{C}$ [15], and much less energy input is required than thermophilic conditions. The entire volume of excess liquid, or leachate, was recirculated daily. The leachate recirculation served as the primary means of mixing since there was no mechanical stirrer. On two occasions (Day 62 and Day 99) the digester was opened and the biomass was manually stirred. The digester was flushed with nitrogen gas after each mixing event to reestablish anaerobic conditions. The biogas production volume, biogas quality (i.e. $\% \mathrm{CH}_{4}, \% \mathrm{CO}_{2}$, and $\% \mathrm{O}_{2}$ ), and digester temperature was also measured and recorded daily.

The rice straw was harvested from a rice field in the Pavia Province of Italy approximately two weeks prior and stored in a dry location. No pretreatment, drying, cutting or milling activities were applied to the rice straw. The straw was collected directly from the field and added to the digester in lengths ranging from 0.2 to $0.6 \mathrm{~m}$. Raw piggery wastewater was collected from a preliminary holding tank at a pig farm in the Pavia Province of Italy. Anaerobic granular sludge was collected from a treatment facility in Eerbeek, the Netherlands, which processes a combined wastewater from five different pulp and paper mill plants.

\subsection{Analytical Methods}

TS and volatile solid (VS) concentrations were measured on the rice straw, piggery wastewater and paper mill sludge prior to placement in the digester. Solids concentrations were also measured on the digestate at the end of the experiment. These analyses were conducted in triplicate and measured according to American Public Health Association (APHA) Standard Methods 2540 [23]. The results of the solids concentrations are summarized in Table $\mathbf{1}$. Biochemical methane potential (BMP) assays were also conducted for the seed mixture (i.e. piggery wastewater and paper mill sludge) in mesophilic conditions to determine if the fraction of methane production coming from the wastewater was significant [24].

A leachate sample was collected daily and analyzed for $\mathrm{pH}$, VFA, carbonate alkalinity $\left(\mathrm{C}_{\mathrm{T}}\right)$, and total ammonia nitrogen (TAN). The leachate analyses were completed as a single sample within two hours of the collection time. The $\mathrm{pH}$ was analyzed with a Hamilton Filltrode probe and was conducted in accordance with the APHA Standard Methods [23]. VFA and $C_{T}$ were analyzed by a titration method using $0.1 \mathrm{M}$ hydrochloric acid $(\mathrm{HCl})$ and acidifying the sample to $\mathrm{pH}$ of 2.2 , while continually recording $\mathrm{pH}$ and using a computer modulation to calculate the results [25]. The TAN concentration $\left(\mathrm{NH}_{3}-\mathrm{N}\right.$ and $\left.\mathrm{NH}_{4}{ }^{+}-\mathrm{N}\right)$ was analyzed using a spectrophotometer (SPT-500) with a Carlo Erba reagent kit (0800.05405). Free ammonia $\left(\mathrm{NH}_{3}-\mathrm{N}\right)$ was calculated from TAN using an equation from Anthonisen et al. that incorporates $\mathrm{pH}$ and temperature [26].

A permanent temperature probe was placed inside the digester and connected to a Gefran digital meter for temperature readings. Biogas volume was measured with an Elster volumetric flow meter $\left(\mathrm{Q}_{\max }-4 \mathrm{~m}^{3} / \mathrm{h}, \mathrm{Q}_{\min }-0.005 \mathrm{~m}^{3} / \mathrm{h}\right)$ and the gas composition was measured with a Geotech biogas analyzer. 


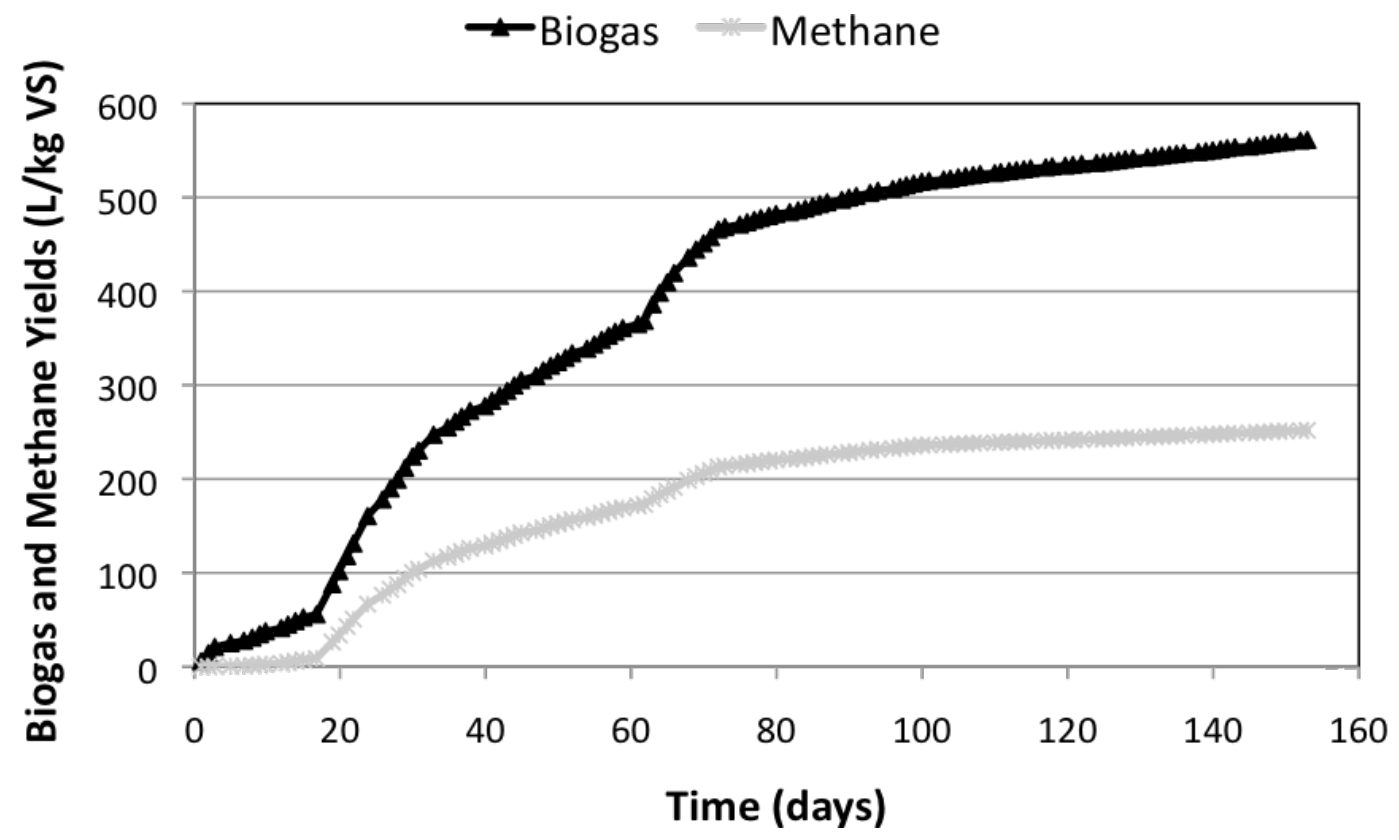

Fig. (1). Specific Biogas and Methane Yields from Digester as a Function of Time.

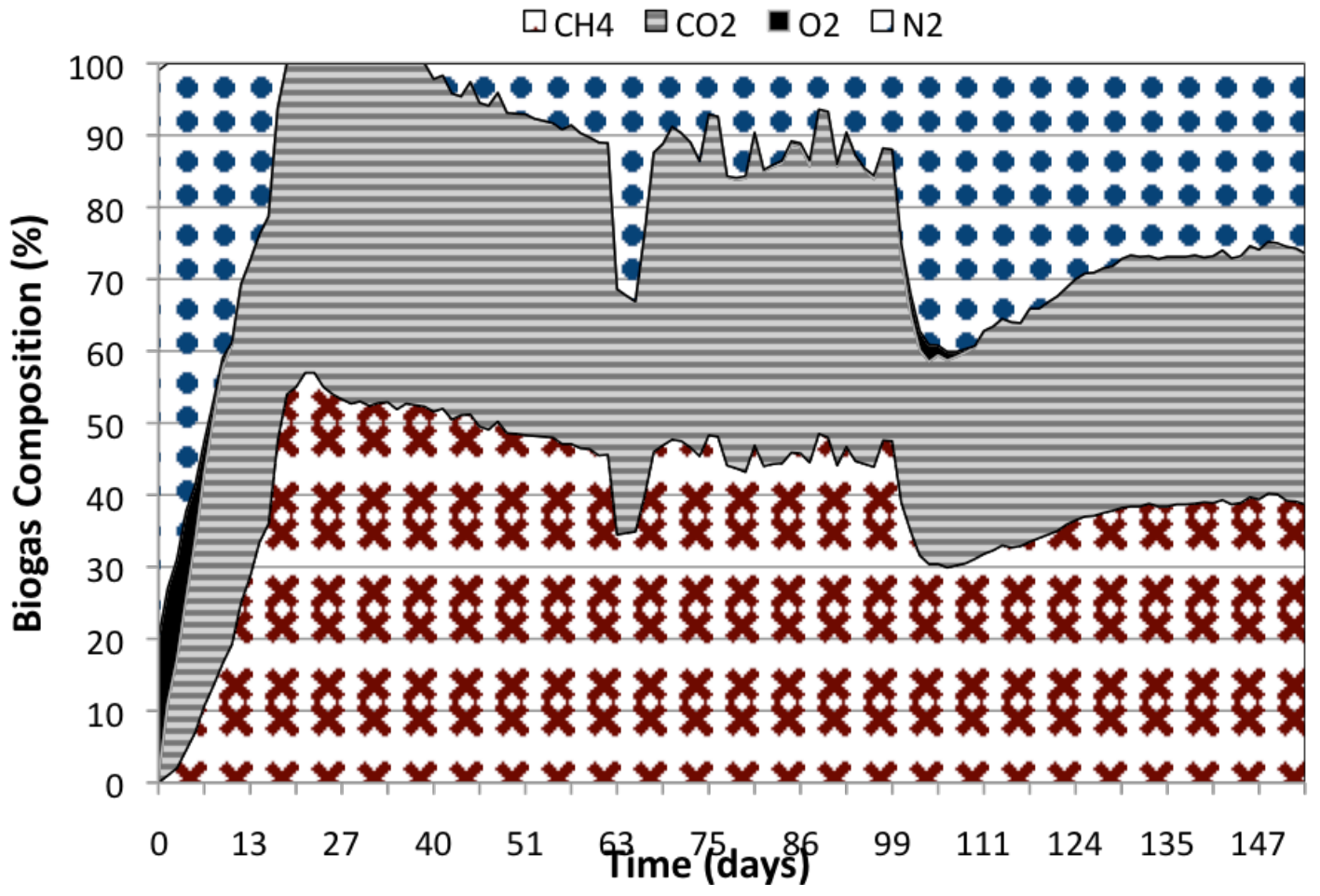

Fig. (2). Biogas Composition from Digester as a Function of Time, Red $\mathrm{X}\left(\mathrm{CH}_{4}\right)$ and Blue $\operatorname{dot}\left(\mathrm{N}_{2}\right)$.

\section{RESULTS AND DISCUSSION}

\subsection{Gas Production}

The specific biogas and methane yields were calculated as the volume of biogas and methane produced per $\mathrm{kg}$ of rice straw VS added, and any contribution of gas production from the inocula mixture was subtracted. The methane produced from the inocula mixture was determined during preliminary biochemical methane potential (BMP) assays containing both piggery wastewater and paper mill sludge. Based on these results, approximately $5 \%$ of the overall methane produced (i.e. $515 \mathrm{~L}$ out of $11,325 \mathrm{~L}$ ) was from the inocula mixture. After subtracting any influence of gas production from the inocula mixture, the specific biogas and methane yields were calculated to be 561 and $252 \mathrm{~L} / \mathrm{kg}$ VS straw added, respectively, for the 153-day digestion cycle. Cumulative yields are shown as a function of time in Fig. (1). 


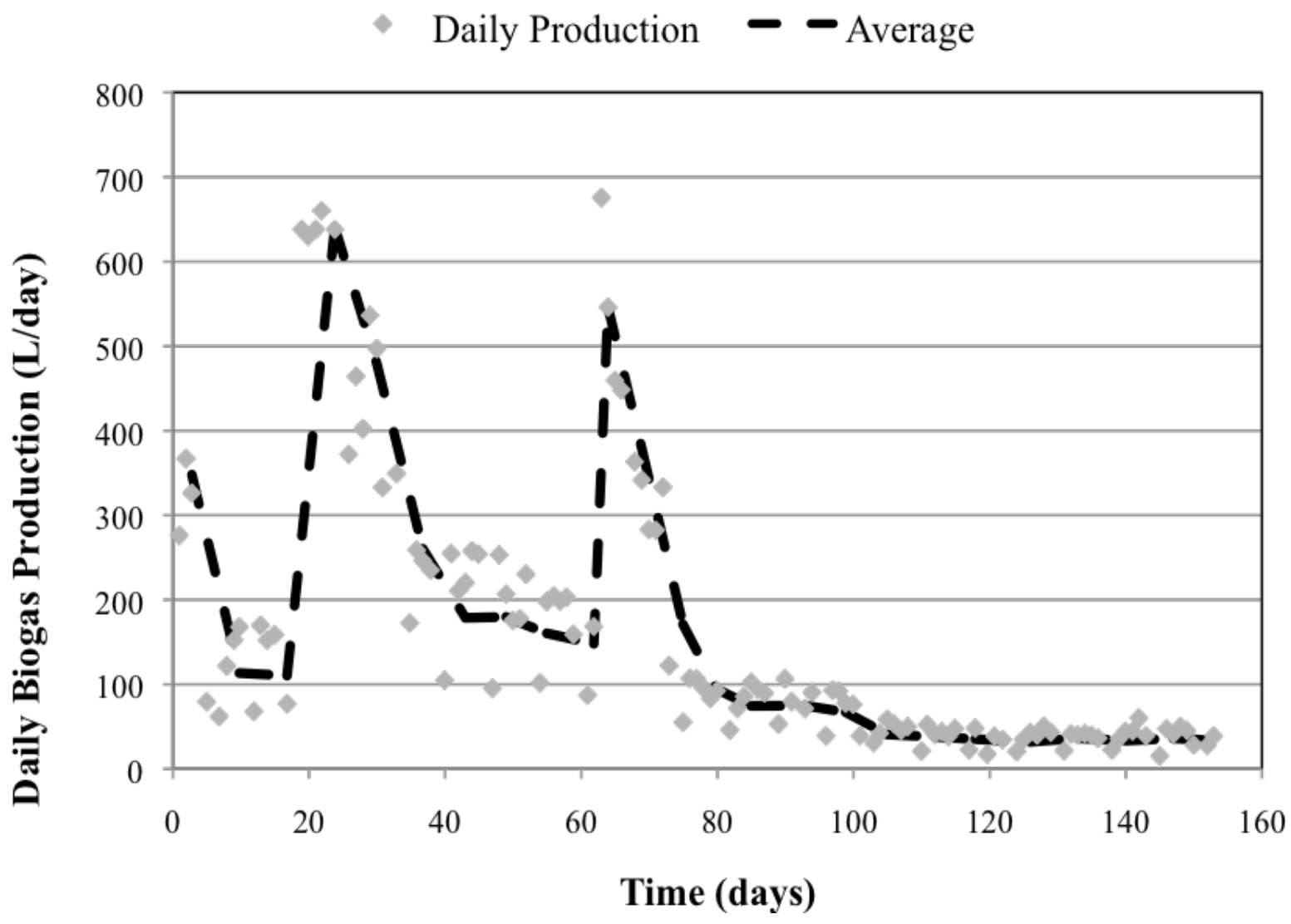

Fig. (3). Daily Biogas Production Rate Measured in Digester.

The average methane content in the biogas was $51 \%$ upon digester stabilization through Day 62 . The biogas quality exceeded $50 \% \mathrm{CH}_{4}$ by Day 19 and reached a maximum of $57 \%$ on Day 22 . The biogas quality was compromised, however, each time the digester was opened for manual stirring (Days 63 and 99), resulting in decreasing $\mathrm{CH}_{4}$ and increasing $\mathrm{N}_{2}$. Slight concentrations of $\mathrm{O}_{2}(0.2$ to $3.0 \%)$ persisted in the digester for 10 days following the second mixing event. The biogas composition $\left(\% \mathrm{CH}_{4}, \% \mathrm{CO}_{2}, \% \mathrm{O}_{2}\right.$, and $\% \mathrm{~N}_{2}$ ) is shown as a function of time in Fig. (2).

The daily biogas production trend shows that $45 \%$ of the biogas was produced within the first 35 days, with an initial peak of 660 L/day on Day 22 (see Fig. 3). Biogas production gradually declined until Day 62 . A second peak of $676 \mathrm{~L} /$ day occurred on Day 63, immediately following the first mixing event in which the digester was opened and manually stirred. The initial mixing event stimulated biogas production for 10 days (through Day 72) followed by a stable decline. The second mixing event on Day 99 had no stimulating effect on gas production, and the residual oxygen generated from opening the digester may have had a detrimental effect. Though the digestion cycle was carried out for 153 days for data collection purposes, the average daily gas production was less than $40 \mathrm{~L} /$ day for the last 50 days. Therefore, $90 \%$ of the overall biogas production and $92 \%$ of the overall methane production was completed by Day 93 . For comparison purposes, a 93-day digestion cycle would have resulted in specific biogas and methane yields of 505 and $231 \mathrm{~L} / \mathrm{kg}$ VS straw added, respectively.

\subsection{VFA Formation and System Stability}

Leachate was recirculated at a rate of $0.2 \mathrm{~m}^{3} / \mathrm{m}^{3}$ straw-day and chemical analysis was performed daily on the leachate samples. The accumulation of VFAs was evident during the first 20 days of the experiment. An initial peak VFA concentration of $6178 \mathrm{mg} \mathrm{HAc/L}$ occurred on Day 8 , and a second smaller peak of $3387 \mathrm{mg} \mathrm{HAc} / \mathrm{L}$ was observed on Day 14. By Day 22, the formation of VFAs was moderate with concentrations ranging from 112 to $739 \mathrm{mg} \mathrm{HAc} / \mathrm{L}$ and averaging $405 \mathrm{mg} \mathrm{HAc} / \mathrm{L}$ for the remainder of the experiment. Although gas production significantly increased as a result of the mixing event on Day 63, there was no corresponding accumulation of VFAs indicating system stability and microbial acclimation.

The $\mathrm{pH}$ and alkalinity were impacted by the initial accumulation of VFAs, but the overall stability of the system was not compromised. During the initial VFA peak on Day 8 , the lowest $\mathrm{pH}$ value $(6.25)$ and alkalinity concentration $(0 \mathrm{mg}$ $\left.\mathrm{CaCO}_{3} / \mathrm{L}\right)$ were observed. The $\mathrm{pH}$ completely recovered by Day 12 and remained stable, ranging from 7.38 to 8.08 , with an average of 7.78 for the duration of the experiment. The alkalinity also showed signs of recovery through Day 12 , but a sudden decrease in alkalinity corresponded with the second VFA peak on Day 14. By Day 22, the alkalinity had completely recovered to $3698 \mathrm{mg} \mathrm{CaCO}_{3} / \mathrm{L}$ and it remained above $2000 \mathrm{mg} \mathrm{CaCO} / \mathrm{L}$ for the rest of the digestion cycle. Fig. (4) shows the trend of VFA concentrations, alkalinity and $\mathrm{pH}$ values measured during the digestion cycle. 


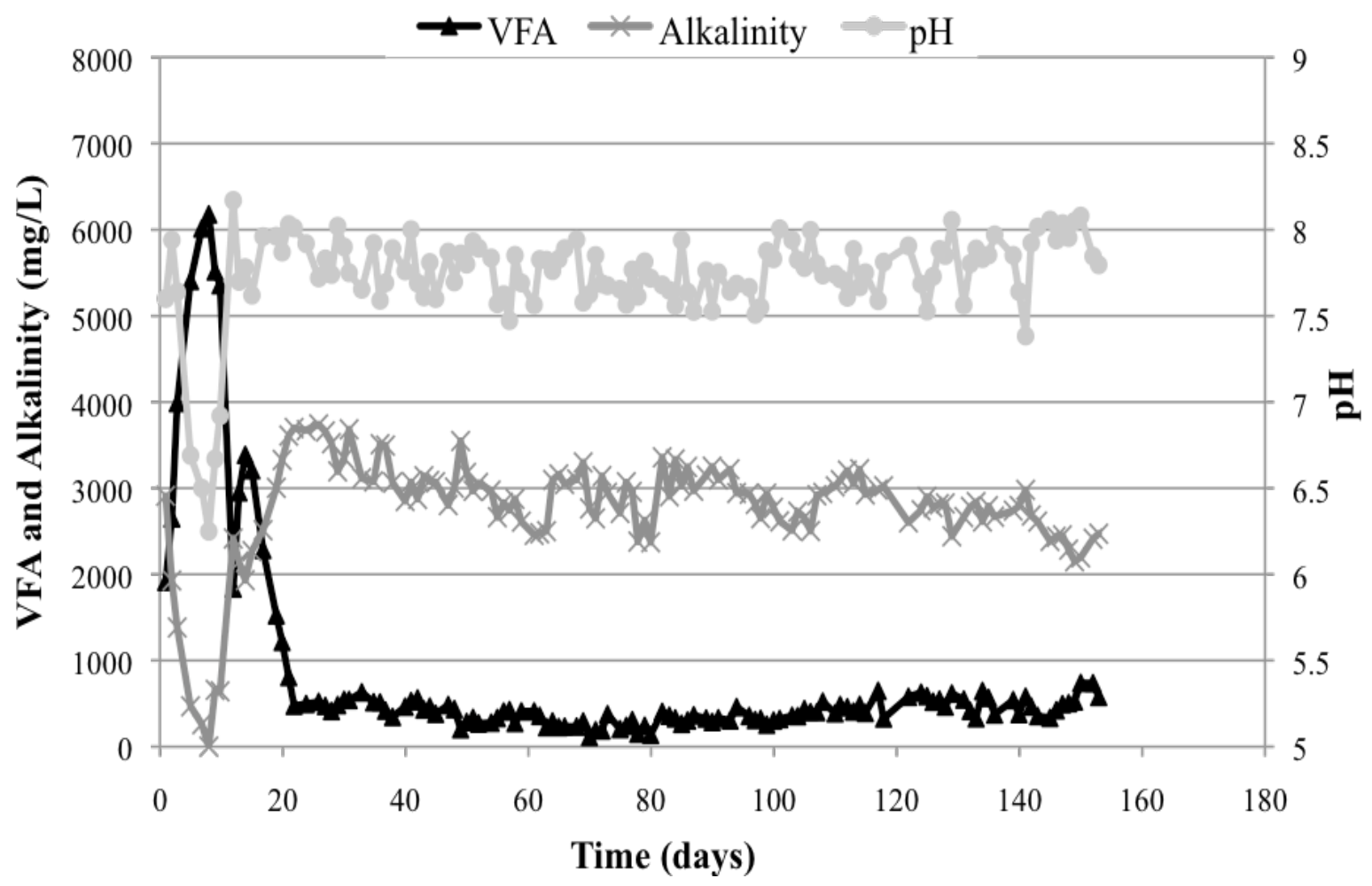

Fig. (4). VFA Concentration (as mg HAc/L), Alkalinity (as $\mathrm{mg} \mathrm{CaCO}_{3} / \mathrm{L}$ ) and $\mathrm{pH}$ Measured in Leachate Samples as a Function of Time.

The ideal temperature range for the anaerobic digestion of rice straw is between 35 and $40^{\circ} \mathrm{C}$ [15]. Excluding the first 24 hours, the digester temperature ranged from 35.2 to $41.0^{\circ} \mathrm{C}$ with an average digester temperature of $37.2^{\circ} \mathrm{C}$.

\subsection{Ammonia Nitrogen Concentrations}

The TAN $\left(\mathrm{NH}_{3}+\mathrm{NH} 4^{+}-\mathrm{N}\right)$ and free ammonia $\left(\mathrm{NH}_{3}\right)$ trends are shown in Fig. (5). Upon mixing the straw with the inocula, the leachate from the digester had an initial TAN concentration of $805 \mathrm{mgN} / \mathrm{L}$. TAN was consumed during the peak gas production phase, resulting in a concentration of $613 \mathrm{mgN} / \mathrm{L}$ on Day 22. Following Day 22, TAN concentrations remained fairly stable between 525 and $626 \mathrm{mg} \mathrm{N} / \mathrm{L}$ with an average concentration of $580 \mathrm{mgN} / \mathrm{L}$. Although some variability was observed from day to day, a distinct oscillation (rise-fall-rise-fall) occurred during the 10 days following the initial mixing event (i.e. Day 63 to 72). The $\mathrm{NH}_{3}$ concentration varied based on the slight changes in temperature and $\mathrm{pH}$, but it remained below $100 \mathrm{mgN} / \mathrm{L}$ except on one occasion. The maximum $\mathrm{NH}_{3}$ concentration (129 $\mathrm{mgN} / \mathrm{L}$ ) occurred on Day 12, which corresponded with the minimum $\mathrm{pH}$ value.

\section{DISCUSSION}

The experiment was carried out for a total of 153 days resulting in a specific methane yield of $252 \mathrm{~L} / \mathrm{kgVS}$. However, after 93 days, over $90 \%$ of the methane production was complete and a specific methane yield of $231 \mathrm{~L} / \mathrm{kgVS}$ was calculated. A comprehensive summary of methane yields obtained for rice straw are reported in a previous literature review [15]. For large-scale applications and economic fea- sibility, it is important to balance maximum energy outputs and minimum biomass retention times. In the current design, a 93-day digestion cycle would be most appropriate to achieve this balance.

The addition of the anaerobic sludge from the pulp and paper mill treatment process resulted in much faster digestion than without sludge. Another pilot-scale system with the same quantity of dry rice straw $(50 \mathrm{~kg})$, twice as much piggery wastewater $(150 \mathrm{~L})$ but no paper mill sludge, and the same operational design parameters $(20 \%$ TS, mesophilic temperature, leachate recirculation) resulted in the same specific methane yield (231 L/kgVS) in 189 days [22].

The acclimation period for the digester without the sludge was much longer with a daily peak gas production on Day 112 [22] versus Day 22 with the sludge, resulting in an overall digestion time that was twice as long. Another major advantage of using the paper mill sludge is that less volume of inocula is required, which reduces costs for acquiring and transporting wastewater. In the current design, the substrate to inocula weight ratio (dry rice straw to piggery wastewater to paper mill sludge) is 1 to 1.25 to 0.5 while the other pilotscale digester was 1 to 3 to 0 [22].

The current pilot-scale digester is an upscale of a previous lab-scale digester ( $1 \mathrm{~L})$ with the same substrate to inocula ratio and operational parameters. The lab-scale digester (D4) had a specific methane yield of $302 \mathrm{~L} / \mathrm{kgVS}$ in a 92-day digestion cycle [21], which is significantly higher than the results obtained in the pilot-scale digester. The primary reason for this difference is the lack of mixing capacity in the pilot-scale reactor. Lack of mixing typically results in less methane production and incomplete digestion since 


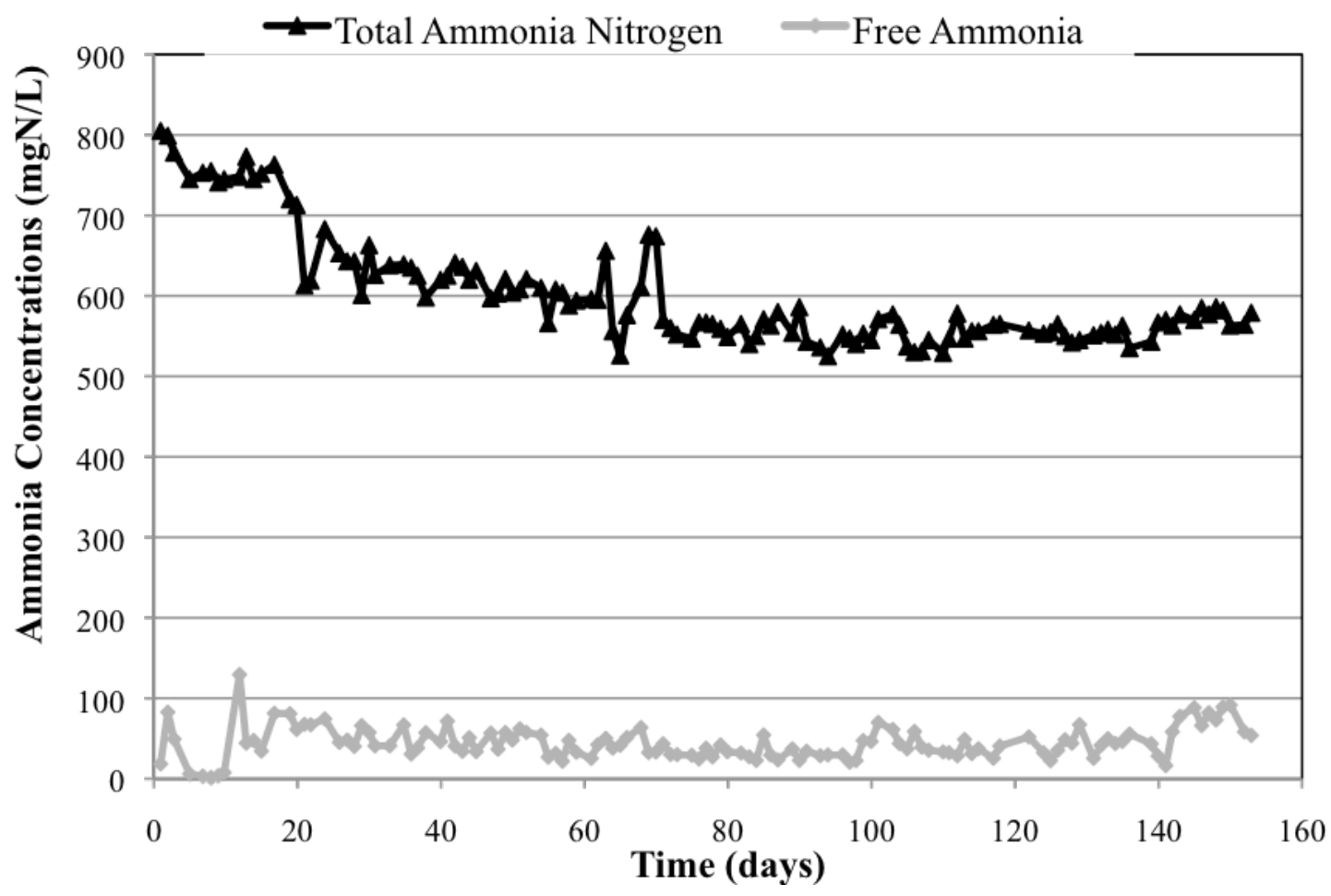

Fig. (5). TAN and Free Ammonia Measured in Leachate Samples as a Function of Time.

there is no uniform distribution of substrate, inocula and enzymes [27]. Internal mixing components for dry digestion systems require lots of energy and maintenance since the material is heavy and immobile. In the lab-scale digester, the contents were stirred by hand to create a homogenous mixture prior to digestion since the volume was manageable and leachate recirculation was not possible. The pilot-scale digester was designed to emulate the farm-scale system in which leachate recirculation is currently the only mechanism used for mixing [18]. The leachate recirculation in the pilotscale digester, however, did not provide adequate mixing and therefore gas production was hindered. This limitation is evident based on the peak in gas production observed after the digester was manually opened and mixed on Day 62 (see Fig. 3) as well as the visual observation when the digester was opened. The black granules of the paper mill sludge were clustered on the top of the straw material, rather than being evenly distributed throughout the digester. Manual mixing to redistribute the sludge material resulted in an immediate increase in gas production in the following days. If the digester contents would have been adequately homogenized at the beginning of the experiment, complete digestion would likely have occurred within a 92-day digestion cycle as observed in the lab-scale digesters [21].

Typically, untreated lignocellulosic material is very difficult to degrade and thus hydrolysis of this material is considered the rate limiting step in the anaerobic digestion process $[9,28]$. However, the production of VFAs in the current pilot-scale digester peaked very quickly within the first two weeks of the digestion cycle followed by peak gas production on Day 22. Two definitive VFA peaks were observed on Day 8 and Day 14, representing the hydrolysis of the piggery wastewater followed by the hydrolysis of the rice straw. Similar VFA trends were observed in the lab-scale digesters (specifically in D3 and D4), where the initial VFA concentration began to decrease rapidly followed by a second peak in production [21]. In the lab-scale digesters, the second peak was associated with the hydrolysis of the straw material, which occurred faster in the digesters containing a higher ratio of paper mill sludge [21]. Based on these observations as well as the increased gas production that followed, it is reasonable to assume that the straw degradation in the pilot-scale digester was occurring by Day 14 of the digestion cycle. Following VFA accumulation, concentrations settled around $400 \mathrm{mgHAc} / \mathrm{L}$ which is within the optimum range of 50 to $500 \mathrm{mgHAc} / \mathrm{L}$ for anaerobic digestion [27], signifying stable digester performance.

The VFA production and specific methane yield observed in this experiment with untreated rice straw in mesophilic conditions are very similar to the results obtained from a pilotscale digester with pretreated rice straw in ambient conditions [29]. The VFA peak production for the digester with pretreated rice straw occurred on Day 10 [29], while the VFA peak with untreated rice straw occurred on Day 14. A specific methane yield of $240 \mathrm{LCH}_{4} / \mathrm{kgVS}$ was achieved after 89 days for the pretreated straw, which is comparable to the results for the untreated straw co-digested with piggery wastewater and paper mill sludge (231 $\mathrm{LCH}_{4} / \mathrm{kgVS}$ in 93 days).

While the paper mill sludge accelerated VFA formation and gas production, the presence and routine recirculation of the piggery wastewater provided sufficient buffer and nutrients to maintain system stability. The digester leachate was slightly acidic (6.25) during peak VFA production but quickly recovered within a couple days. The alkalinity sup- 
plied by the piggery wastewater was sufficient (approximately $3,000 \mathrm{mgCaCO}_{3} / \mathrm{L}$ ) to prevent an extreme drop in $\mathrm{pH}$, and the TAN concentrations were adequate but not inhibitory for the anaerobic digestion process [27, 30].

\section{CONCLUSIONS}

The addition of paper mill sludge with piggery wastewater in a pilot-scale digester of untreated rice straw operated in dry, mesophilic conditions accelerated VFA formation and gas production. The untreated rice straw with the sludge yielded $231 \mathrm{LCH}_{4} / \mathrm{kg}$ VS within a 93-day digestion cycle compared to 189 days without the sludge. Although the digestion cycle was initially carried out to 153 days, the 93day digestion cycle was determined to be the optimum time period to balance the maximum energy output with the minimum retention time. Daily leachate recirculation $\left(0.2 \mathrm{~m}^{3} / \mathrm{m}^{3}\right.$ straw-day) was not adequate for internal mixing and homogenization of the digester material, which is necessary to achieve maximum gas production within the shortest time period. This co-digestion approach is feasible for application to the farm-scale digester, as it would improve methane production, reduce the retention time of the straw, and reduce the quantity of piggery wastewater needed for the optimum digestion conditions.

Future studies should focus on improving the mixing capacity in the existing system as well as the potential for using continuous anaerobic reactor configurations for dry systems such as Dranco, Valorga or Kompogas. To better understand the microbial consortium responsible for the improved digestion with the paper mill sludge, microbiological evaluations should be conducted on samples collected at the beginning and throughout the digestion process to identify the specific microorganisms present in the mixture.

\section{CONFLICT OF INTEREST}

The authors confirm that this article content has no conflicts of interest.

\section{ACKNOWLEDGEMENTS}

This research was funded by the Erasmus Mundus Joint Doctorate program ETeCoS ${ }^{3}$ (Environmental Technologies for Contaminated Solids, Soils and Sediments) under the EU grant agreement FPA n2010-0009 and also by the company Acqua e Sole s.r.l. as an associate member of the $\mathrm{ETeCoS}^{3}$ consortium. Representatives from Acqua e Sole provided the basis of the study design, all the necessary equipment to carry out the experiments, laboratory support for the analyses, and assistance in the data interpretation. The authors would like to thank Erasmus Mundus for funding for this research program and Acqua e Sole s.r.l. for their help and support throughout the project. A special thanks to Filip ("Pippo") Pitu for the digester set-up, Fabrizio Boari for his machine operator skills and Yuri Lazzarini for his consistent help and support.

\section{REFERENCES}

[1] I. S. Arvanitoyannis and P. Tserkezou, "Corn and rice waste: a comparative and critical presentation of methods and current and potential uses of treated waste," Int. J. Food. Sci. Technol., vol. 43, pp. 958-88, 2008.

[2] R. R. Bakker and B. M. Jenkins, "Feasibility of collecting naturally leached rice straw for thermal conversion," Biomass. Bioenergy., vol. 25, pp. 597-614, 2003.

[3] Y. F. Huang, W. H. Kuan, S. L. Lo, and C. F. Lin, "Hydrogen-rich fuel gas from rice straw via microwave-induced pyrolysis," Bioresour. Technol., vol. 101, pp. 1968-73, 2010.

[4] J. L. Shie, F. J. Tsou, K. L. Lin, and C. Y. Chang, "Bioenergy and products from thermal pyrolysis of rice straw using plasma torch," Bioresour. Technol., vol. 101, pp. 761-8, 2010.

[5] Y. Sun and J. Cheng, "Hydrolysis of lignocellulosic materials for ethanol production: a review," Bioresour. Technol., vol. 83, pp. 1-11, 2002.

[6] Y. Shinozaki and H. K. Kitamoto, "Ethanol production from ensiled rice straw and whole-crop silage by the simultaneous enzymatic saccharification and fermentation process," J. Biosci. Bioeng., vol. 111, pp. 320-5, 2011.

[7] EurObserv'er, "Biogas barometer," Le Journal des Energies Renouvelables, vol. 200, pp. 104-19, 2010.

[8] M. Lubken, T. Gehring, and M. Wichern, "Microbiological fermentation of lignocellulosic biomass: current state and prospects of mathematical modeling," Appl. Microbiol. Biotechnol., vol. 85, pp. 1643-52, 2010.

[9] X. Tong, L. H. Smith, and P. L. McCarty, "Methane fermentation of selected lignocellulosic materials," Biomass, vol. 21, pp. 239-55, 1990 .

[10] A. Ghosh and B. B.C., "Biomethanation of white rotted and brown rotted rice straw," Bioprocess. Eng., vol. 20, pp. 297-302, 1999

[11] Y. He, Y. Pang, Y. Liu, X. Li, and K. Wang, "Physicochemical characterization of rice straw pretreated with sodium hydroxide in the solid state for enhancing biogas production," Energy. Fuels., vol. 22, pp. 2775-81, 2008.

[12] A. T. Hendriks and G. Zeeman, "Pretreatments to enhance the digestibility of lignocellulosic biomass," Bioresour. Technol., vol. 100 , pp. 10-8, 2009.

[13] R. Zhao, Z. Zhang, R. Zhang, M. Li, Z. Lei, M. Utsumi, and N. Sugiura, "Methane production from rice straw pretreated by a mixture of acetic-propionic acid," Bioresour. Technol., vol. 101, pp. 990-4, 2010.

[14] A. Lehtomaki, S. Huttunen, and J. A. Rintala, "Laboratory investigations on co-digestion of energy crops and crop residues with cow manure for methane production: Effect of crop to manure ratio " Resour. Conserv. Recycl., vol. 51, pp. 591-609, 2007.

[15] W. Mussoline, G. Esposito, P. Lens, and A. Giordano, "The anaerobic digestion of rice straw: A review," Crit. Rev. Environ. Sci. Technol., vol. 43, pp. 895-915, 2013.

[16] M. S. Kalra and J. S. Panwar, "Anaerobic digestion of rice crop residues," Agric. Wastes., vol. 17, pp. 263-9, 1986.

[17] G. Sun, Y. Wu, S. Sha, and K. Liu, "Dry digestion of crop wastes: studies on dry anaerobic digestion with agricultural wastes," Biol. Wastes, vol. 20, pp. 291-302, 1987.

[18] W. Mussoline, G. Esposito, P. Lens, G. Garuti, and A. Giordano, "Electrical energy production and operational strategies from a farm-scale anaerobic batch reactor loaded with rice straw and piggery wastewater," Renew. Energy., vol. 62, pp. 399-406, 2014.

[19] Y. Tamaru, H. Miyake, K. Kuroda, A. Nakanishi, Y. Kawade, K Yamamoto, M. Uemura, Y. Fujita, R. H. Doi, and M. Ueda, "Genome sequence of the cellulosome-producing mesophilic organism Clostridium cellulovorans 743B," J. Bacteriol., vol. 192, pp. 901-2, 2010.

[20] Y. Tamaru, H. Miyake, K. Kuroda, M. Ueda, and R. H. Doi, "Comparative genomics of the mesophilic cellulosome-producing Clostridium cellulovorans and its application to biofuel production via consolidated bioprocessing," Environ. Technol., vol. 31, pp. 889-903, 2010.

[21] W. Mussoline, G. Esposito, P. Lens, A. Spagni, and A. Giordano, "Enhanced methane production from rice straw co-digested with anaerobic sludge from pulp and paper mill treatment process," Bioresour. Technol., vol. 148, pp. 135-143, 2013.

[22] W. Mussoline, G. Esposito, P. Lens, G. Garuti, and A. Giordano, "Design considerations for a farm-scale biogas plant based on pilotscale anaerobic digesters loaded with rice straw and piggery wastewater," Biomass Bioenergy., vol. 46, pp. 469-78, 2012. 
[23] APHA, Standard Methods for the Examination of Water and Wastewater 20th ed. Washington DC: American Public Health Association/American Water Works Association/Water Environment Federation 1998.

[24] J. M. Owens and D. P. Chynoweth, "Biochemical methane potential of municipal solid waste (MSW) components," Water. Sci. Technol., vol. 27, pp. 1-14, 1993.

[25] O. Lahav, B. E. Morgan, and R. E. Loewenthal, "Rapid, simple, and accurate method for measurement of VFA and carbonate alkalinity in anaerobic reactors," Environ. Sci. Technol., vol. 36, pp. 2736-41, 2002.

[26] A. C. Anthonisen, R. C. Loehr, T. B. Prakasam, and E. G. Srinath, "Inhibition of nitrification by ammonia and nitrous acid," J. Water Pollut. Control. Fed., vol. 48, pp. 835-52, 1976.
[27]

T. Amani, M. Nosrati, and T. R. Sreekrishnan, "Anaerobic digestion from the viewpoint of microbiological, chemical, and operational aspects - a review," Environ. Rev., vol. 18, pp. 255-278, 2010 .

[28] W. S. Adney, C. J. Rivard, S. A. Ming, and M. E. Himmel, "Anaerobic digestion of lignocellulosic biomass and wastes. Cellulases and related enzymes," Appl. Biochem. Biotechnol., vol. 30, pp. 16583, 1991.

[29] L. Lianhua, L. Dong, S. Yongming, M. Longlong, Y. Zhenhong, and K. Xiaoying, "Effect of temperature and solid concentration on anaerobic digestion of rice straw in South China," Int. J. Hydrogen. Energy., vol. 35, pp. 7261-6, 2010.

[30] Y. Chen, J. J. Cheng, and K. S. Creamer, "Inhibition of anaerobic digestion process: a review," Bioresour. Technol., vol. 99, pp. 4044-64, 2008.

(C) Wendy Mussoline et al.; Licensee Bentham Open.

This is an open access article licensed under the terms of the Creative Commons Attribution Non-Commercial License (http://creativecommons.org/licenses/by-nc/3.0/g) which permits unrestricted, non-commercial use, distribution and reproduction in any medium, provided the work is properly cited. 